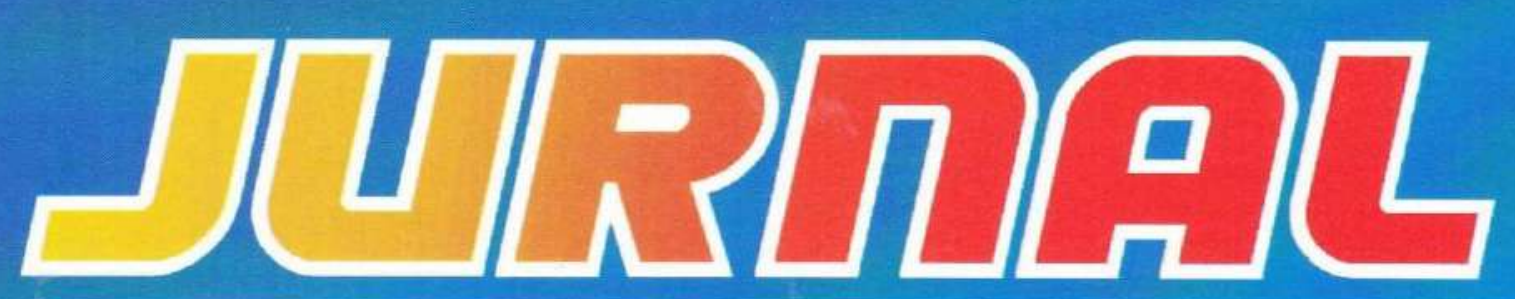

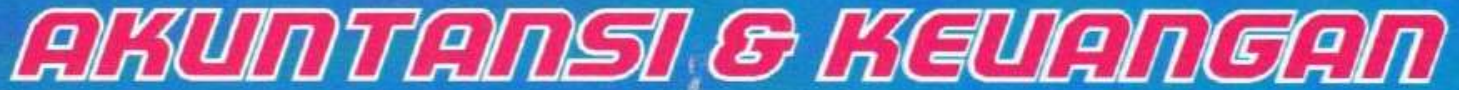

Volume 11, No. 1, Maret 2020

ISSN: $2087-2054$

Analisa Perbandingan Economic Value Added (EVA) Dan Return On Asset (ROA) Dalam Menilai Kinerja Perusahaan (Studi Kasus Pada Perusahaan Rokok Yang Terdaftar Di Bursa Efek Indonesiaperiode 2015-2018).

\section{Dewi Silvia}

Analisis Kinerja Anggaran Pendapatan Dan Belanja Daerah Pada Pemerintah Daerah Kabupaten Oku Periode 2013-2017

Hasiatul Aini, Mardiah Kenamon \& Yeni Anggraini

Analisis Kinerja Keuangan Pemerintah Daerah Oku Selatan Tahun Anggaran 2013-2017. Anis Feblin \& Yulitiawati

Pengaruh Economic Value Added (EVA) Dan Market Value Added (MVA) Terhadap Return Saham.

\section{Luke Suciyati Amna}

Analisis Rasio Keuangan Anggaran Pendapatan Dan Belanja Daerah Untuk Menilai Kinerja Keuangan Pemerintah Daerah Kabupaten Pesawaran Tahun 2010-2014.

\section{Herry Goenawan Soedarsa}

Pengaruh Kualitas Audit Dan Komite Audit Terhadap Kualitas Pelaporan Keuangan Perusahaan Yang Terdaftar Di Jakarta Islamic Index (JII).

\section{Liya Ermawati, Yulistia Devi \& Naurah Nazhifah Arramadani}




\section{JURNAL}

ARUNTANSI \& KEUANGAN

Volume 11, No. 1, Maret 2020

ISSN: $2087-2054$

Dewan Pembina

Dr. Ir. M. Yusuf S. Barusman, M.B.A

Dr. Andala Rama Putra Barusman, S.E., M.A.Ec.

Penanggung Jawab

Aminah, S.E., M.S.Ak

Pimpinan Redaksi

Dr. Haninun, S.E., M.S.Ak

Sekretaris Redaksi

Riswan, S.E., M.S.Ak

Luke Suciyati Amna, S.E., M.S.Ak

\section{Penyuting Ahli (Mitra Bestari)}

Tina Miniawati, S.E., M.B.A. (Universitas Trisakti)

Dr. Khomsiyah, S.E., M.M. (Universitas Trisakti)

Dr. Lindrianasari, S.E., M.Si.Akt., C.A. (Universitas Lampung)

Sujoko Efferin, Mcom (Hons), MA(Econ), Ph.D. (Universitas Surabaya)

\section{Penerbit}

Universitas Bandar Lampung

Fakultas Ekonomi dan Bisnis Program Studi Akuntansi

SENARAI-Jurnal Akuntansi \& Keuangan Terbit 2 kali setahun pada bulan Maret \&

September

Artikel yang dimuat berupa hasil riset Empiris dan telaah teoritis konsepsual yang kritis dalam kajian bidang akuntansi, auditing, perpajakan, dan keuangan.

\section{Alamat Redaksi}

Gedung G- Program Studi Akuntansi Fakultas Ekonomi dan Bisnis

Universitas Bandar Lampung

Kampus A Jalan Z.A Pagar Alam No. 26 Labuan Ratu Bandar Lampung 35142

Telp: (0721) 701979, Fax: (0721) 701467, Email: Prodi.akuntansi@ubl.ac.id 


\section{AKUNTANSI \& KEUANGAN}

Analisa Perbandingan Economic Value Added (EVA) Dan Return On Asset (ROA) Dalam Menilai Kinerja Perusahaan (Studi Kasus Pada Perusahaan Rokok Yang Terdaftar Di Bursa Efek Indonesiaperiode 2015-2018).

\section{Dewi Silvia}

Analisis Kinerja Anggaran Pendapatan Dan Belanja Daerah Pada Pemerintah Daerah Kabupaten Oku Periode 2013-2017

Hasiatul Aini, Mardiah Kenamon \& Yeni Anggraini

Analisis Kinerja Keuangan Pemerintah Daerah Oku Selatan Tahun Anggaran 2013-2017. Anis Feblin \& Yulitiawati

Pengaruh Economic Value Added (EVA) Dan Market Value Added (MVA) Terhadap Return Saham.

\section{Luke Suciyati Amna}

Analisis Rasio Keuangan Anggaran Pendapatan Dan Belanja Daerah Untuk Menilai Kinerja Keuangan Pemerintah Daerah Kabupaten Pesawaran Tahun 2010-2014.

\section{Herry Goenawan Soedarsa}

Pengaruh Kualitas Audit Dan Komite Audit Terhadap Kualitas Pelaporan Keuangan Perusahaan Yang Terdaftar Di Jakarta Islamic Index (JII).

Liya Ermawati, Yulistia Devi \& Naurah Nazhifah Arramadani 


\section{JURNAL}

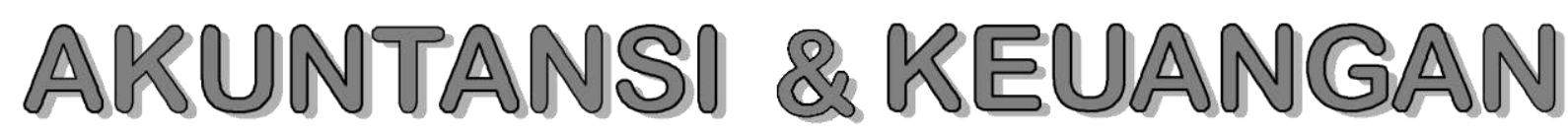

Volume 11, No. 1, Maret 2020

ISSN: $2087-2054$

Daftar Isi

Halaman

Analisa Perbandingan Economic Value Added (EVA) Dan Return On Asset (ROA) Dalam Menilai Kinerja Perusahaan (Studi Kasus Pada

Perusahaan Rokok Yang Terdaftar Di Bursa Efek Indonesiaperiode 2015-2018).

Dewi Silvia

Analisis Kinerja Anggaran Pendapatan Dan Belanja Daerah Pada

Pemerintah Daerah Kabupaten Oku Periode 2013-2017

18-34

Hasiatul Aini, Mardiah Kenamon \& Yeni Anggraini

Analisis Kinerja Keuangan Pemerintah Daerah Oku Selatan Tahun Anggaran 2013-2017.

$35-58$

Anis Feblin \& Yulitiawati

Pengaruh Economic Value Added (EVA) Dan Market Value Added (MVA)

Terhadap Return Saham.

$59-73$

Luke Suciyati Amna

Analisis Rasio Keuangan Anggaran Pendapatan Dan Belanja Daerah Untuk Menilai Kinerja Keuangan Pemerintah Daerah Kabupaten

Pesawaran Tahun 2010-2014.

Herry Goenawan Soedarsa

Pengaruh Kualitas Audit Dan Komite Audit Terhadap Kualitas Pelaporan

Keuangan Perusahaan Yang Terdaftar Di Jakarta Islamic Index (JII).

$92-111$

Liya Ermawati, Yulistia Devi \& Naurah Nazhifah Arramadani 


\section{JURNAL \\ AKUNTANSI \& KEUANGAN}

Volume 11, No. 1, Maret 2020

ISSN: 2087-2054

\section{Informasi Kebijakan dan Selingkung Berkala}

\section{Kebijakan editorial}

JURNAL Akuntansi \& Keuangan adalah sebuah berkala yang dipublikasikan oleh Universitas Bandar Lampung, yang bertujuan untuk menjadi wadah kreatifitas para akademisi, profesional, peneliti, dan mahasiswa di bidang Akuntansi dan Keuangan termasuk juga bidang Auditing, Sistem Informasi Akuntansi, Tata kelola Perusahaan, Perpajakan, Akuntansi Internasional, Akuntansi Managemen, Akuntansi Keperilakuaan, Pasar Modal dan lain sebagainya. Topik yang semakin meluas di bidang kajian riset Akuntansi diakomodir publikasinya di dalam berkala ini.

Paper yang akan dipublikasikan di dalam berkala JURNAL Akuntansi \& Keuangan harus ditulis di dalam bahasa Indonesia yang baik dan sesuai dengan EYD. Semua instrumen yang digunakan untuk memperoleh data penelitian harus dimasukkan di dalam lampiran paper penelitian, paling tidak, penulis bersedia memberikan klarifikasi atas instrumen yang digunakan saat ada permintaan dari peneliti lainnya.

\section{Sekretariat Editor Berkala}

Gedung F - Fakultas Ekonomi Universitas Bandar Lampung

Fakultas Ekonomi Program Studi Akuntansi

Kampus A Jalan Z.A. Pagar Alam No. 26 Labuhan Ratu Bandar Lampung 35142

Telp.: (0721) 701979, Fax.: (0721) 701467, Email:

\section{Petunjuk penulisan}

Artikel yang dikirim ke JURNAL Akuntansi \& Keuangan harus mengikuti petunjuk seperti berikut:

1. Naskah merupakan naskah asli yang belum pernah diterbitkan atau sedang dilakukan penilaian pada berkala lain. Naskah ditulis dalam bahasa Indonesia dengan jarak 1 spasi, sepanjang 20-30 halaman kertas A4 dengan tipe huruf Times New Roman.. Naskah dikirim atau diserahkan ke sekretariat JURNAL Akuntansi \& Keuangan rangkap satu disertai disket berikut dengan biodata penulis dan alamat lengkap (kantor dan rumah) pada lembaran yang terpisah dari halaman pertama artikel.

2. Judul naskah dapat ditulis dengan menggambarkan isi pokok tulisan, dan atau ditulis secara ringkas, jelas, dan menarik.

3. Nama Penulis disertai catatan kaki tentang profesi dan lembaga tempat penulis bekerja dalam naskah yang telah diterima untuk diterbutkan.

4. Abstrak ketik satu spasi, tidak lebih dari 250 kata dalam bahasa Inggris. Abstrak memuat tujuan penelitian, isu, permasalahan, sampel dan metode penelitian, serta hasil dan simpulan (jika memungkinan). 
5. Pendahuluan beriksikan uraian tentang latar belakang masalah, ruang lingkup penelitian, dan telaah pustaka yang terkait dengan permasalahan yang dikaji, serta rumusan hipotesis (jika ada). Uraian pendahuluan maksimum $10 \%$ total halaman.

6. Untuk penelitian kuantitatif,

a. Telaah Literatur dan Pengembangan Hipotesis memuat paling tidak satu buah teori yang menjadi dasar pemikiran penelitian. Hipotesis dikembangkan menggunakan asumsi dasar teori dan hasil penelitian sebelumnya. Telah literatur maksimum $40 \%$ total halaman.

b. Metodologi Penelitian meliputi uraian yang rinci tentang bahan yang digunakan, metoda yang dipilih, teknik, dan cakupan penelitian. Uraian bahan dan metoda maksimum $20 \%$ total halaman.

7. Untuk penelitian kualitatif menyesuaikan dengan metodologi kualitatif.

8. Hasil dan Pembahasan merupakan uraian obyektif dari-hasil penelitian dan pembahasan dilakukan untuk memperkaya makna hasil penelitian. Uraian hasil dan pembahasan minimum $25 \%$ total halaman.

9. Simpulan yang merupakan rumusan dari hasil-hasil penelitian. Harus ada sajian dalam satu kalimat inti yang menjadi simpulan utama. Simpulan maksimum $10 \%$ dari keseluruhan lembar artikel.

10. Referensi (Daftar Pustaka) ditulis berurutan berdasarkan alphabetical, disusun menggunakan suku kata terakhir dari nama penulisnya, atau institusi jika dikeluarkan oleh organisasi.

a. Buku: nama penulis, tahun penerbitan, judul lengkap buku, penyunting (jika ada), nama penerbit, dan kota penerbitan.

b. Artikel dalam buku: nama penulis, tahun penerbitan, judul artikel/tulisan, judul buku, nama penyunting, kota penerbitan, nama penerbit, dan halaman.

c. Terbitan berkala: nama penulis, tahun penerbitan, judul tulisan, judul terbitan (bila disingkat, sebaiknya menggunakan singkatan yang baku), volume, nomor, dan halaman.

d. Artikel dalam internet: nama penulis, judul, dan situsnya.

e. Tabel diberi nomor dan judul dilengkapi dengan sumber data yang ditulis dibawah badan tabel, diikuti tempat dan waktu pengambilan data.

f. Ilustrasi dapat berupa gambar, grafik, diagram, peta, dan foto diberi nomor dan judul.

11. Setiap referensi yang digunakan di dalam naskah artikel menggunakan petunjuk yang dirujuk pada The Indonesian Journal of Accounting Research, sebagai berikut:

A. Kutipan dalam tubuh naskah paper harus disesuaikan dengan contoh berikut:

I. Satu sumber kutipan dengan satu penulis (Brownell, 1981).

II. Satu sumber kutipan dengan dua penulis (Frucot dan Shearon, 1991).

III. Satu sumber kutipan dengan lebih dari satu penulis (Hotstede et al., 1990).

IV. Dua sumber kutipan dengan penulis yang berbeda (Dunk, 1990; Mia, 1988).

V. Dua sumber kutipan dengan satu penulis (Brownell, 1981, 1983).

VI. Dua sumber kutipan dengan satu penulis diterbitkan pada tahun yang sama (Brownell, 1982a, 1982b).

VII. Sumber kutipan dari lembaga harus dinyatakan dengan menggunakan akronim institusi (FASB, 1994)

B. Setiap artikel harus menulis referensi menggunakan panduan berikut:

I. Referensi harus tercantum dalam urutan abjad dari nama belakang penulis atau nama lembaga. 
II. Referensi harus dinyatakan dengan urutan sebagai berikut: penulis (s) nama, tahun publikasi, judul kertas atau buku teks, nama jurnal atau penerbit dan nomor halaman. Contoh:

a) Amerika Akuntansi Association, Komite Konsep dan Standar Laporan Keuangan Eksternal. 1977. Pernyataan tentang Teori Akuntansi dan Teori Penerimaan. Sarasota, FL: AAA.

b) Demski, J. S., dan D. E. M. Sappington. 1989. Struktur hirarkis dan akuntansi pertanggungjawaban, Jurnal Akuntansi Penelitian 27 (Spring): 40-58.

c) Dye, R. B., dan R. Magee. 1989. Biaya Kontijensi untuk perusahaan audit. Kertas kerja, Northwestern University, Evansto, IL.

d) Indriantoro, N. 1993. Pengaruh Penganggaran Partisipatif Terhadap Prestasi Kerja dan Kepuasan Kerja dengan Locus of Control dan Dimensi Budaya sebagai Moderating Variabel. Ph.D. Disertasi. University of Kentucky, Lexington.

e) Naim, A. 1997. Analisis Penggunaan Akuntansi Biaya Produk Dalam Keputusan Harga oligopolistik. Jurnal Ekonomi Dan Bisnis Indonesia 12 (3): 43-50.

f) Porcano, T. M. 1984a. Keadilan distributif dan Kebijakan Pajak. Akuntansi Ulasan 59 (4): 619-636.

g) --------. 1984b. Pengaruh Persepsi Kebijakan Pajak Niat Investasi Perusahaan. The Journal of American Association Perpajakan 6 (Fall): 719.

h) Pyndyk, R. S. dan D. L. Rubinfield. 1987. Model ekonometrik \& Forecasts Ekonomi, 3rd ed. NY: McGraw-Hill Publishing, Inc.

12. Author(s) harus melampirkan CV, alamat email, alamat korespondensi dan pernyataan yang menyatakan pasal tersebut tidak sedang disampaikan kepada atau diterbitkan oleh jurnal lain dalam email tersebut dan /atau pos. 
JURNAL Akuntansi\& Keuangan

Vol. 11, No. 1, Maret 2020

Halaman $92-111$

\title{
PENGARUH KUALITAS AUDIT DAN KOMITE AUDIT TERHADAP KUALITAS PELAPORAN KEUANGAN PERUSAHAAN YANG TERDAFTAR DI JAKARTA ISLAMIC INDEX (JII)
}

\author{
Liya Ermawati* \\ Yulistia Devi* \\ Naurah Nazhifah Arramadani**
}

(*Dosen Tetap Fakultas Ekonomi dan Bisnis Universitas Islam Negeri Lampung)

(*Dosen Tetap Fakultas Ekonomi dan Bisnis Universitas Islam Negeri Lampung)

Email: Liyaermawati@ radenintan.ac.id.

Email: yulistiadevi@ radenintan,ac.id.

\begin{abstract}
The current era of free trade globalization, companies are led to present financial reporting that can provide information needed by users. With the company presenting financial reporting, the company's economic conditions can be known by outside parties. The quality of financial reporting is related to the overall performance of the company which is reflected in corporate profits and the performance of the company's capital market which is realized in the form of rewards. Every company must have audit quality, because all operational activities in the company have a set standard in order to achieve the company's goals and objectives. The Financial Accounting Standard Board (FASB) has realized that the audit committee (internal auditor) has involvement in the financial reporting process and actively contributes to creating more effective corporate governance practices. The audit quality function functions to oversee management together with the audit committee. In good corporate governance, the resulting financial reporting is even better. The Government of Indonesia in 2000 issued a sharia stock index, the Jakarta Islamic Index (JII). The Jakarta Islamic Index (JII) is a sharia stock index consisting of 30 most liquid stocks of issuers whose business activities do not conflict with sharia principles. the performance of the Jakarta Islamic Index (JII) began to be seen in 2018 where its performance exceeded the performance of the JCI where during
\end{abstract}


Pengaruh Kualitas Audit dan Komite Audit Terhadap Kualitas Pelaporan ........(Liya Ermawati, Yulistia Devi dan Naurah Nazhifah Arramadani)......

the last six years the performance of the JCI has always been above the performance of the Jakarta Islamic Index (JII). This study aims to analyze the effect of audit quality on the quality of financial statements, the influence of the audit committee on the quality of financial statements and the effect of audit quality and the audit committee together on the quality of financial statements of companies listed on the Jakarta Islamic Index (JII). The sample of this study consisted of 30 companies registered in the Jakarta Islamic Index (JII) in 2016-2017 which were determined through purposive sampling, this study used multiple regression analysis techniques. The results show that: a) audit quality affects the quality of financial reporting; b) the audit committee has no effect on the quality of financial reporting; and c) simultaneously audit quality and audit committee influence the quality of financial reporting.

Keywords: Audit Quality, Audit Committee, and Quality of Financial Reports.

\section{A. Latar Belakang}

Di Indonesia pada tanggal 30 Juli 2000, PT Bursa Efek Indonesia bekerja sama dengan PT Danareksa Investment Management (DIM) meluncurkan indeks saham yang dibuat berdasarkan syariah islam yaitu Jakarta Islamic Index (JII). Index ini diharapkan menjadi tolak ukur kinerja saham-saham yang berbasis syariah serta untuk lebih mengembangkan pasar modal syariah.

Presentase investor syariah terhadap total investor di Pasar Modal Indonesia terus mengalami peningkatan dalam jumlah yang signifikan. Pada tahun 2014, presentasenya baru mencapai 0,7\%, maka di 2015 meningkat menjadi $1,1 \%$, tahun 2016 meningkat menjadi 2,3\%, dan mencapai $3,1 \%$ per agustus $2017 .{ }^{1}$

Setiap perusahaan wajib memiliki kualitas audit, karena seluruh kegiatan operasional yang ada pada perusahaan memiliki standar yang ditetapkan agar dapat bertahan dalam mencapai tujuan dan sasaran perusahaan. Sehingga manajemen perusahaan dalam segala aktivitas kegiatan perusahaan harus dapat membuat sebuah system dengan baik yang dikendalikan oleh sebuah kualitas audit yang ada padaperusahaan.

Kualitas audit merupakan probabilitas seorang auditor dalam menemukan dan melaporkan suatu kekeliruan atau penyelewengan yang terjadi dalam suatu sistem akuntansi klien. Kualitas audit tercermin dari orientasi masukan yang meliputi: Penugasan personel oleh KAP, untuk

\footnotetext{
${ }^{1}$ Jakarta Islamic Index (JII)" (On-line), tersedia di:https://www.sahamok.com/bei/indeks-bursa/jakarta-islamic-index-jii/ (10 Januari 2019)
} 
melaksanakan perjanjian, konsultasi, supervisi, pengangkatan, pengembangan profesi, promosi dan inspeksi; Orientasi proses meliputi: indepensendi, kepatuhan pada standar audit, pengendalian audit, dan kompetensi auditor; Orientasi keluaran meliputi: kinerja auditor, penerimaan dan kelangsungan kerjasama dengan klien, dan due professional care; Tindak lanjut atas rekomendasi audit yang meliputi: jajaran manajemen klien mendukung implementasi rekomendasi auditor; Peraturan internal klien memungkinkan untuk mengimplementasikan rekomendasi audit; Sistem di perusahaan klien memungkinkan untuk mengimplementasikan rekomendasi dari auditor; dan fasilitas fisik di perusahaan klien memungkinkan untuk mengimplementasikan rekomendasi dari auditor. ${ }^{2}$

Kualitas pelaporan keuangan dapat dipandang dalam dua sudut pandang. Pandangan pertama menyatakan bahwa kualitas pelaporan keuangan berhubungan dengan kinerja keseluruhan perusahaan yang tercermindalam laba perusahaan. Pandangan ini menyatakan bahwa laba yang berkualitas tinggi terefleksikan pada laba yang dapat berkesinambungan untuk suatu periode yang lama. Pandangan kedua menyatakan bahwa kualitas pelaporan keuangan berkaitan dengan pasar kinerja pasar modal yang diwujudkan dalam bentuk imbalan, sehingga hubungan yang semakin kuat antara laba perusahaan dengan imbalan menunjukkan informasi pelaporan keuangan yang tinggi. ${ }^{3}$

Komite audit mempunyai peran yang cukup vital dalam proses terlaksananya suatu mekanisme tata kelola perusahaan yang baik. Adanya komite audit ini membantu dalam penerapan good corporate governance. Komite audit sendiri seperti sudah dijelaskan merupakan sebuah komite yang dibuat oleh dewan komisiaris dalam rangka membantu dewan komisiaris melakukan tugas pengawasan. ${ }^{4}$

Dari penjelasan diatas peneliti ingin meneliti factor apa yang mempengaruhi kualitas pelaporan keuangan pada perusahaan yang terdaftar di Jakarta Islamic Index. Oleh sebab itu peneliti mencoba untuk meneliti dengan indicator kualitas pelaporan keuangan tersebut diantaranya kualitas audit, dan komite audit.

\section{B. LANDASAN TEORI}

\footnotetext{
${ }^{2}$ Mathius Tandiontong, Kualitas Audit dan Pengukurannya (Bandung: Alfabeta, 2015), h. 73 .

${ }^{3}$ Rizki Rudiantoro, Sylvia Veronica Siregar, "Kualitas Keuangan UMKM Serta Prospek Implementasi SAK ETAP”. Jurnal Akuntansi dan Keuangan Indonesia, Vol. 9 No. 01 (Juni 2012), h. 2.

${ }^{4}$ Alvin Chandra, "Pengaruh Efektivitas Komite Audit Terhadap Relevasi Nilai Laba Bersih dan Arus Kas Dari Kegiatan Operasi”. (Tesis, Program Manajemen Kekhususan Manajemen Keuangan, Universitas Indonesia, Jakarta, 2011), h. 14.
} 
Pengaruh Kualitas Audit dan Komite Audit Terhadap Kualitas Pelaporan .(Liya Ermawati, Yulistia Devi dan Naurah Nazhifah Arramadani).....

a. Teori Keagenan (AgencyTheory)

Teori keagenan (Agency Theory) dari Jensen dan Meckling; Scott; yang memandang sebagai suatu versi dari game theory yang membuat suatu model kontraktual antara dua atau lebih orang (pihak), dimana salah satu pihak disebut agen dan pihak yang lain disebut principal. Principal medelegasikan pertanggung jawaban atas decision making kepada agent, hal ini dapat pula dikatakan bahwa principal memberikan suatu amanah kepada agent untuk melaksanakan tugas tertentu sesuai dengan kontrak kerja yang telah disepakati. Wewenang dan tanggung jawab agent maupun principal diatur dalam kontrak kerja atas persetujuan bersama.Teori agensi menyatakan perlunya jasa independen auditor dapat dijelaskan dengan dasar teori keagenan, yaitu hubungan antara pemilik (principal) dengan manajemen (agent). ${ }^{5}$

\section{b. Teori Kualitas Audit}

Kualitas audit dapat diartikan sebagai bagus tidaknya suatu pemeriksaan yang telah dilakukan oleh auditor. Berdasarkan Standar Profesional Akuntan Publik (SPAP) audit yang dilaksanakan auditor dapat dikatakan berkualitas, jika memenuhi ketentuan atau standar pengauditan. Standar auditing mencakup mutu profesional, auditor independen, pertimbangan (judgement) yang digunakan dalam pelaksanaan audit dan penyusunan laporan audit. ${ }^{6}$

Berdasarkan Standar Profesional Akuntan Publik (SPAP), bahwa audit yang dilaksanakan auditor dapat dikatakan berkualitas jika memenuhi ketentuan atau standar auditing. Standar auditing mencakup mutu professional (professional qualities) auditor independen, pertimbangan (judgement) yang digunakan dalam pelaksanaan audit dan penyusunan laporan auditor.

Dari pengertian tentang kualitas audit diatas, maka dapat disimpulkan bahwa kualitas audit merupakan segala kemungkinan probability) dimana auditor pada saat mengaudit aporan keuangan kita dapat menemukan pelanggaran yang terjadi dalam system akuntansi klien dan melaporkannya dalam laporan keuangan auditan, dimana dalam melaksanakan tugasnya tersebut auditor berpedoman pada standar auditing dan kode etik akuntan public yang relevan. Tetapi dalam menjalankan fungsinya, auditor ssering mengalami konflik 2015), h. 3-6.

${ }^{5}$ Mathius Tandiontong, Kualitas Audit dan Pengukurannya (Bandung: Alfabeta,

${ }^{6}$ Muhammad Fahdi, "Pengaruh Independensi dan Kompetensi Terhadap Kualitas Audit (Studi Empiris Pada Inspektorat Seprovinsi Riau)". Jurnal Valuta, Vol. 4 No. 2 (Oktober 2018), h. 88 . 
kepentingan dengan manajemen perusahaan. Manajemen ingin operasi perusahaan atau kinerjanya tampak berhasil, salah satunya tergambar melalui laba yang lebih tinggi dengan maksud untuk menciptakan penghargaan.

\section{c. Teori Komite Audit}

Komite audit adalah sejumlah anggota dewan komisiaris perusahaan klien yang bertanggung jawab untuk membantu auditor dalam mempertahankan independensinya dari manajemen. Umumnya komite audit terdiri dari tiga atau lima atau kadang tujuh orang yang tidak merupakan bagian dari manajemen perusahaan. ${ }^{8}$

Komite audit mempunyai peran yang cukup vital dalam proses terlaksananya suatu mekanisme tata kelola perusahaan yang baik. Adanya komite audit ini membantu dalam penerapan good cororate governance. Komite audit sendiri seperti sudah dijelaskan merupakan sebuah komite yang dibuat oleh dewan komisiaris dalam rangka membantu dewan komisiaris melakukan tugas pengawasan. ${ }^{9}$

Komite audit bertugas membantu dewan komisaris untuk memonitor proses pelaporan keuangan oleh manajemen untuk meningkatkan kredibilitas laporan keuangan. Tugas komite audit meliputi menelaah kebijakan akuntansi yang diterapkan oleh perusahaan, menilai pengendalian internal, menelaah sistem pelaporan eksternal dan kepatuhan terhadap peraturan.

Komite audit juga bertugas sebagai pihak penengah apabila terjadi selisih pendapat antara menajemen dan auditor mengenai interpretasi dan penerapan prinsip akuntansi yang berlaku umum untuk mencapai keseimbangan akhir sehingga laporan lebih akurat.

\section{d. Teori Kualitas Laporan Keuangan}

Kinerja keuangan didedikasikan sebagai gambaran dari pencapaian keberhasilan perusahaan dapat diartikan sebagai hasil yang telah dicapai atas berbagai aktivitas yang telah dilakukan. Dari hasil analisis tersebut nantinya akan dapat diketahui tingkat kesehatan perusahaan dan juga dapat diketahui kelemahan maupun prestasi yang dimiliki oleh perusahaan, sehingga pihak-pihak yang berkepentingan akan dapat menggunakannya sebagai bahan dalam

\footnotetext{
${ }^{7}$ Pancawati Hardiningsih, " Pengaruh Independensi, Corporate Governance, dan Kualitas Audit Terhadap Integritas Laporan Keuangan”. Kajian Akuntansi, Vol. 2 No. 1 (Pebruari 2010), h. 64-65.

8 Amir Abadi Jusuf, Auditing Pendekatan Terpadu (Jakarta, Salemba Empat, 2003), h. 89.

${ }^{9}$ Alvin Chandra, "Pengaruh Efektivitas Komite Audit Terhadap Relevasi Nilai Laba Bersih dan Arus Kas Dari Kegiatan Operasi”. (Tesis, Program Manajemen Kekhususan Manajemen Keuangan, Universitas Indonesia, Jakarta, 2011), h. 14.
} 
Pengaruh Kualitas Audit dan Komite Audit Terhadap Kualitas Pelaporan (Liya Ermawati, Yulistia Devi dan Naurah Nazhifah Arramadani).

pengambilan keputusan. ${ }^{10}$

Menurut Jonas dan Blanchett tahun 2000 kualitas laporan keuangan adalah informasi yang lengkap dan transparan, dirancang tidak menyesatkan kepada pengguna. Kualitas laporan keuangan sangat berpengaruh pada akuntabilitas, dengan kualitas laporan keuangan yang baik akan memberikan dedikasi terhadap akuntabilitas atau pertanggungjawaban atas laporan keuangan yang dibuat yang akan berpengaruh terhadap pemberian opini atas kewajaran informasi keuangan yang disajikan.

Karakteristik kualitatif laporan keuangan adalah ukuran-ukuran normatif yang perlu diwujudkan dalam informasi akuntansi sehingga dapat memenuhi tujuannya. Dalam Peraturan Pemerintah Nomor 71 Tahun 2010 menyatakan karakteristik kualitatif laporan keuangan pemerintah antara lain:

1) Relevan Laporan keuangan dapat dikatakan relevan jika informasi yang termuat di dalamnya dapat mempengaruhi keputusan pengguna dengan membantu mereka mengevaluasi peristiwa masa lalu atau masa kini dan memprediksi masa depan, serta mengoreksi hasil evaluasi mereka di masa lalu.

2) Andal yaitu informasi dalam laporan keuangan bebas dari pengertian yang menyesatkan dan kesalahan material, menyajikan setiap fakta secara jujur, serta dapat diverifikasi.

3) Dapat dibandingkan, yaitu informasi yang termuat dalam laporan keuangan akan lebih berguna jika dapat dibandingkan dengan laporan keuangan periode sebelumnya atau laporan keuangan entita pelaporan lain pada umumnya.

4) Dapat dipahami, yaitu informasi yang disajikan dalam laporan keuangan dapat dipahami oleh pengguna dan dinyatakan dalam bentuk serta istilah yang disesuaikan dengan batas pemahaman para pengguna. ${ }^{11}$

\section{e. Tinjauan Pustaka}

1) Penelitian yang dilakukan oleh Rizqy Alfya Puteri pada tahun 2019 yang berjudul "Pengaruh komisaris independen, kepemilikan institusional, komite audit, ukuran perusahaan dan leverage terhadap integritas laporan keuangan perusahaan LQ 45 periode 2013-2017.” Hasil penelitian menunjukkan

${ }^{10}$ Munawir, Analisa Laporan Keuanggan (Yogyakarta: Liberty, 2007), h. 5.

11 Desi Puspitawati, "Analisis Faktor-Faktor Yang Mempengaruhi Kualitas Laporan Keuangan Pemerintah Daerah”. (Tesis Ilmu Akuntansi Universitas Lampung, Bandar Lampung, 2016), h. 10. 
bahwakomisiarisindependen dan kepemilikan institusional memiliki pengaruh yang signifikan terhadap integritas laporan keuangan, sedangkan komite audit, ukuran perusahaan dan leverage tidak berpengaruh terhadap integritas laporan keuangan.

2) Penelitian yang dilakukan oleh Shabrina Rahutami Nur Amalia yang berjudul "pengaruh auditor internal terhadap pelaporan keuangan pada bank perkreditan rakyat di Jawa Tengah".Hasil penelitian ini menunjukkan bahwa auditor internal mempengaruhi kualitas pelaporan keuangan. Kordinasi dan kerjasama antara auditor internal dan auditor eksternal memiliki pengaruh positif terhadap peningkatan kualitas pelaporan keuangan.

3) Penelitian yang dilakukan oleh Badewin pada tahun 2019 yang berjudul "Pengaruh kepemilikan institusional, komite audit, dan kualitas audit terhadap integritas laporan keuangan pada perusahaan manufaktur yang terdaftar di BEI."Hasil penelitian menunjukkan komite audit dan kualitas audit berpengaruh terhadap integritas laporan keuangan, sedangkan kepemilikan institusional tidak berpengaruh terhadap integritas laporan keuangan

\section{f. Kerangka Pemikiran}

Dalam sebuah penelitian dibutuhkan kerangka berfikir untuk menjelaskan arah dari penelitian tersebut. Didalam kerangka berfikir dapat menunjukkan hubungan antara variabel independen dan variabel dependen. Adapun kerangka berfikir dalam penelitian ini adalah:

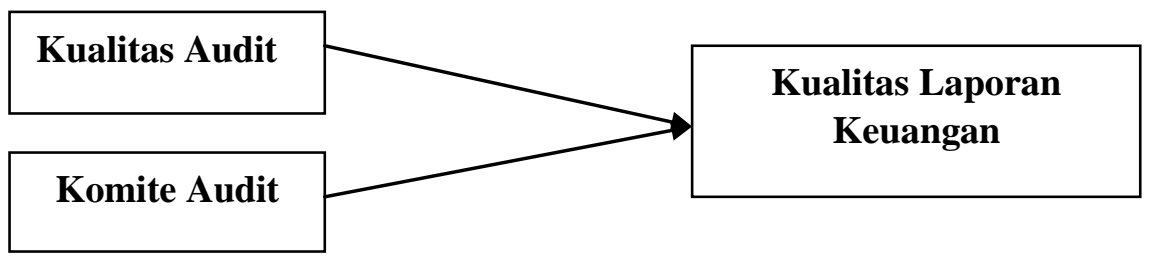

1) Variabel independen (bebas) dalam penelitian ini adalah Kualitas Audit ( $\left.\mathrm{X}_{1}\right)$ dan Komite $\operatorname{Audit}\left(\mathrm{X}_{2}\right)$.

2) Variabel dependen (terikat) dalam penelitian ini adalah Kualitas Laporan Keuangan.

\section{g. Hipotesis}

1) Pengaruh kualitas audit terhadap kualitas laporan keuangan

Kualitas audit dapat diartikan sebagai bagus tidaknya suatu 
pemeriksaan yang telah dilakukan oleh auditor. Berdasarkan Standar Profesional Akuntan Publik (SPAP) audit yang dilaksanakan auditor dapat dikatakan berkualitas, jika memenuhi ketentuan atau standar pengauditan. Standar auditing mencakup mutu profesional, auditor independen, pertimbangan (judgement) yang digunakan dalam pelaksanaan audit dan penyusunan laporan audit. ${ }^{12}$

Kualitas laporan keuangan adalah suatu analisis yang dilakukan untuk melihat sejauh mana suatu perusahaan telah melaksanakan dengan menggunakan aturan-aturan pelaksanaan keuangan secara baik dan benar. Penelitian sebelumnya Badewin pada tahun 2019 menunjukkan bahwa variabel KAP berpengaruh terhadap integritas laporan keuangan.

Ho : Kualitas audit tidak berpengaruh terhadap kualitas laporan keuangan $\mathrm{H} 1$ : Kualitas audit berpengaruh terhadap kualitas laporan keuangan.

\section{2) Pengaruh Komite Audit Terhadap Kualitas Laporan \\ Keuangan}

Komite audit bertugas membantu dewan komisaris untuk memonitor proses pelaporan keuangan oleh manajemen untuk meningkatkan kredibilitas laporan keuangan. ${ }^{13}$ Di dalam pelaksanaan tugasnya komite menyediakan komunikasi formal antara dewan, manajemen, auditor eksternal, dan auditor internal. Adanya komunikasi formal antara komite audit, auditor internal, dan auditor eksternal akan menjamin proses audit internal dan eksternal dilakukan dengan baik. ${ }^{14}$

kualitas laporan keuangan adalah suatu analisis yang dilakukan untuk melihat sejauh mana suatu perusahaan telah melaksanakan dengan menggunakan aturan-aturan pelaksanaan keuangan secara baik dan benar. Penelitian sebelumnya Badewin pada tahun 2019 menunjukkan bahwa variabel komite audit yang diproksikan dengan jumlah anggota komite audit yang dimiliki perusahaan terhadap integritas laporan keuangan

Ho : Komite audit tidak berpengaruh terhadap kualitas

${ }^{12}$ Muhammad Fahdi, "Pengaruh Independensi dan Kompetensi Terhadap Kualitas Audit (Studi Empiris Pada Inspektorat Seprovinsi Riau)". Jurnal Valuta, Vol. 4 No. 2 (Oktober 2018), h. 88. 2003), h. 89

13 Amir Abadi Jusuf, Auditing Pendekatan Terpadu (Jakarta, Salemba Empat,

${ }^{14}$ Agung Suaryana, "Pengaruh Komite Audit Terhadap Kualitas Laba". kajian Akuntansi, Vol. 2 No. 1 (Pebruari 2010), h. 13. 
laporan keuangan $\mathrm{H} 2$ : Komite audit berpengaruh terhadap kualitas laporan keuangan.

\section{METODE PENELITIAN}

\section{Metode dan Sifat Penelitian}

Penelitian ini menggunakan pendekatan kuantitatif. Metode penelitian kuantitatif dapat diartikan sebagai metode penelitian yang berlandaskan pada filsafat positivisme, digunakan untuk meneliti pada populasi atau sempel tertentu, pemgumpulan data menggunakan instrument penelitian, analisis data bersifat kuantitatif/statistic, dengan tujuan untuk menguji hipotesis yang telah ditetapkan. ${ }^{15}$

\section{Sumber Data}

Data yang dikumpulkan untuk penelitian ini adalah data sekunder yaitu data yang bersumber dari catatatn yanga ada pada perusahaan dan dari sumber lainnya yaitu dengan mengadakan studi kepustakaan dengan mempelajari buku-buku yang ada hubungannya dengan objek penelitian atau dapat dilakukan dengan menggunakan data dari Biro Pusat Statistik. $^{16}$

\section{Populasi dan Sampel}

Jumlah populasi dalam penelitian ini adalah 30 perusahaan yang terdaftar pada Jakarta Islamic Index (JII) selama 2 tahun.

Sampel adalah sebagian kecil dari jumlah karakteristik yang dimiliki oleh populasi. ${ }^{17}$ Sedangkan metode pengumpulan sampel yang digunakan dalam penelitian ini adalam Purposive Sampling, dan indikator yangdigunakan harus sesuai dengan kriteria yang digunakan untuk memilih sampel adalah sebagai berikut :

a. Perusahaan yang terdaftar di Jakarta Islamic Index (JII) periode tahun 2016 tahun 2017.

b. Perusahaan yang terdaftar di Jakarta Islamic Index (JII) yang mengeluarkan laporan keuangan dan laporan tahunan (Annual Report) 2 tahun secara berturut-turut selama periode 2016-2017.

c. Perusahaan yang terdaftar di Jakarta Islamic Index (JII) yang memiliki kelengkapan data yang dibutuhkan dalam penelitian ini selama periode pengamatan.

\section{Definisi OperasionalVariabel}

\section{a. Variabel Dependen(Y)}

${ }^{15}$ Sugiono,Metode Penelitian Pendidikan Pendekatan Kualitatif, Kuantitatif, dan $R \& D$, Cetakan ke-26 (Bandung: Alfabeta, 2017), h. 8. Alfabeta, 2016). h. 9.

16 Sugiono. Metode Penelitian Kuantitatif, Kualitatif dan $R \& D$ (Bandung:

${ }_{17}$ J.Supranto, Tehnik Sampeling Untuk Survey Dan Eksperimen, (Jakarta: Rineka Cipta, 2007). h. 37. 
Variabel dependen merupakan variabel yang dipengaruhi atau yang menjadi akibat karena adanya variabel bebas. ${ }^{18}$ Variabel dependen dalam penelitian ini adalah kualitas laporan keuangan. Dalam penelitian ini untuk mengukur kualitas laporan keuangan menggunakan Rasio On Assets(ROA). Untuk mendapatkan nilai ROA dilakukan dengan langkah - langkah sebagai berikut :

\section{Rasio On Assets = Net Income/Total Aset $x$ 100\%}

b. Variabel Independen $(\mathbf{X})$

1) KualitasAudit

Kualitas audit merupakan segala kemungkinan (probability) dimana auditor pada saat mengaudit laporan keuangan dapat menemukan pelanggaran yang terjadi dalam system akuntansi klien dan melaporkannya dalam laporan keuangan auditan, dimana dalam melaksanakan tugasnya tersebut auditor berpedoman pada standar auditing dan kode etik akuntan publik yang relevan. ${ }^{19}$

Dalam penelitian ini kualitas audit diukur melalui ukuran KAP tempat auditor tersebut berkerja, yang dibedakan menjadi KAP Big Four dan KAP Non-Big Four. KAP big four adalah KAP yang memiliki keahlian dan reputasi tinggi dibanding dengan KAP non-big four. Kantor Akuntan Publik yang termasuk dalam kelompok big four dan yang bercabang di Indonesia adalah:

a) KAP Purwantono, Sarwoko, dan Sandjaja yang berafiliasi dengan Ernst and Young (E \&Y)

b) KAP Tanudiredja, Wibisana, dan Rekan. Yang berafiliasi dengan Pricewaterhouse Coopers(PwC)

c) KAP Satrio Bing Eny \& Rekan. Yang berafiliasi dengan Deloitte Touche Thomatsu (DTT)

d) KAP Siddharta, dan Widjaja yang berafiliasi dengan Klynveld Peat Marwick Goerdeler(KPMG)

e) Ukuran KAP diukur dengan skala nominal melalui variabel dummy. Angka 1 digunakan untuk mewakili perusahaan yang diaudit oleh KAP Big Four dan angka 0 digunakan untuk mewakili perusahaan yang tidak diaudit oleh KAP Non-BigFour.

\section{2) Komite Audit}

18 Tulus Suryanto. “Manajemen Laba Pada Bank Syariah Di Indonesia: Peran Komite Audit Dan Dewan Pengawas Syariah” KINERJA, Vol. 18 No. 1 (2014), h. 96

${ }^{19}$ Pancawati Hardiningsih, " Pengaruh Independensi, Corporate Governance, dan Kualitas Audit Terhadap Integritas Laporan Keuangan”. Kajian Akuntansi, Vol. 2 No. 1 (Pebruari 2010), h. 64-65. 
Komite audit adalah sejumlah anggota dewan komisaris perusahaan klien yang bertanggung jawab untuk membantu auditor dalam mempertahankan independensinya dari manajemen. $^{20}$ Dalam penelitian ini komite audit diukur dengan jumlah anggota dalam suatu perusahaan yang terdapat pada sampel penelitian.

\section{Teknik PengumpulanData}

\section{a. Studi Pustaka}

Dalam penelitian ini penulis menggunakan metode pustaka yang berasal dari jurnal-jurnal yang berkaitan dengan judul yang diteliti, buku-buku literature, dan penelitian sejenisnya

\section{b. Dokumentasi}

Metode dokumentasi adalah tehnik pengumpulan data dengan melihat dokumen yang sudah tersedia. ${ }^{21}$ Data atau informasi yang berkaitan degan penelitian ini dari website masing-masing perusahaan yang terdaftar di Jakata Islamic Index (JII) dan artikel terkait penelitian.

\section{Metode Analisis Data}

\section{a. Uji Asumsi Klasik}

Pengujian asumsi klasik merupakan uji prasyarat jika menggunakan analisis regresi linear. Uji ini antara lain uji normalitas residual, uji multikolinearitas, uji heteroskedasitas, dan uji autokorelasi. Jika asumsi tersebut dilanggar, missal model regresi tidak normal, terjadi multikolinearitas, terjadi heterodasitas atau terjadi gejala autokorelasi. Maka hasil analisis regresi dan pengujian seperti uji $\mathrm{t}$ dan $\mathrm{f}$ menjadi tidak valid atau bias. ${ }^{22}$

1) Uji Normalitas

2) Uji multikolinearitas

3) Uji Auto Korelasi

4) Uji Heteroskedastisitas

5) Uji Statistik Deskriptif

Statistik deskriptif adalah statistik yang digunakan untuk menganalisis data dengan cara mendeskripsikan atau menggambarkan data yang telah terkumpul sebagaimana adanya tanpa bermaksud membuat kesimpulan yang berlaku untuk

${ }^{20}$ Amir Abadi Jusuf, Auditing Pendekatan Terpadu (Jakarta, Salemba Empat, 2003), h. 89.

${ }^{21}$ Prof. Sugiono. Metode Penelitian Kuantitatif, Kualitatif dan $R \& D$ ((Bandung: Alfabeta, 2016), h. 224

${ }^{22}$ Suharyadi Purwanto, Statistika untuk Ekonomi dan Keuangan Modern (Jakarta: Salemba Empat,2016), h. 30. 
umum atau generalisasi. ${ }^{23}$

\section{b. Regresi Linear Berganda}

Dalam menguji hipotesis yang diajukan dalam penelitian ini, peneliti menggunakan metode analisis regresi linier berganda. Regresi linier berganda dilakukan terhadap model yang diajukan meggunakan software SPSS dan digunakan untuk menguji pengaruh variabel independen (X) yaitu kualitas audit (X1) dan komite audit (X2) terhadap kualitas pelaporan keuangan (Y) sebagai variabel dependen.

Persamaan regresi yang digunakan adalah sebagai berikut:

$$
\begin{aligned}
& \mathrm{Y}=\mathrm{a}+\mathrm{b}_{1} \mathrm{X}_{1}+\mathrm{b} 2 \mathrm{X} 2 \\
& \mathrm{Y}: \text { variabel terikat (kualitas laporan } \\
& \text { keuangan) } \\
& \mathrm{a}: \text { konstanta } \\
& \mathrm{b} 1-\mathrm{b} 2: \\
& \text { koefisien } \\
& \text { regresi } \\
& \mathrm{X} 1: \text { kualitas } \\
& \text { audit } \\
& \mathrm{X} 2 \text { : komite audit }
\end{aligned}
$$

\section{c. Uji Hipotesis}

Uji t dilakukan untuk menguji pengaruh masing-masing variabel independen terhadap variabel dependen. Apabila nilai signifikan dari t hitung kurang dari 0.05 maka hipotesis yang menyatakan bahwa terdapat pengaruh yang signifikan antara variabel independen dan variabel dependen diterima. ${ }^{24}$

\section{HASIL PENELITIAN}

\section{Analisis data}

a. Uji Normalitas

Berdasarkan Hasil Output menggunakan uji kolmogorof smirnov, diketahui bahwa nilai signifikansi 0,599>0,05 sehingga dapat disimpulkan bahwa data penelitian yang uji berdistribusi normal.

b. Uji Multikolinearitas

Berdasarkan output coefficients Uji Multikolinearitas, bahwa nilai tolerance lebih dari 0,1 yaitu 0,833 dan nilai VIF kedua

\footnotetext{
${ }^{23}$ Agus Tri Basuki dan Nano Prawoto, Analisis Regresi dalam Penelitian Ekonomi dan Bisnis (dilengkapi aplikasi SPSS \& EVIEWS).... h. 96.

${ }^{24}$ Alvin Chandra, "Pengaruh Efektivitas Komite Audit terhadap Relevansi Nilai Laba dan Arus Kas dari Kegiatan Operasi". (Tesis Program Megister Manajemen Kekhususan Manajemen Keuangan, Jakarta, 2011), h. 54.
} 
variabel kurang dari 10 yaitu 1,200 maka dapat disimpulkan bahwa model regresi bebas dari multikolinearitas atau tidak adanya masalah multikolinearitas

c. Uji Auto Korelasi

Diketahui nilai Asymp. Sig. (2-talled) sebesar 0,195 > 0,05, maka dapat disimpulkan bahwa tidak terdapat gejala autokorelasi.

d. Uji Heteroskedastisitas

Berdasarkan hasil Uji Heteroskedastisitas dapat diketahui bahwa nilai signifikansi untuk variabel kualitas audit (X1) adalah 0,162 dan nilai signifikansi variabel komiteaudit(X2)dalah0,400karenanilaisignifikansikeduavariabe llebih besar dari 0,05 hal ini berarti bahwa tidak terjadi heteroskedastisitaspada model regresi, sehingga model regresi layak digunakan untuk memprediksi Kualitas Pelaporan Keuangan berdasarkan masukan variabel independennya.

\section{Uji Statistik Deskriptif}

\section{Tabel 4.1}

Descriptive Statistics

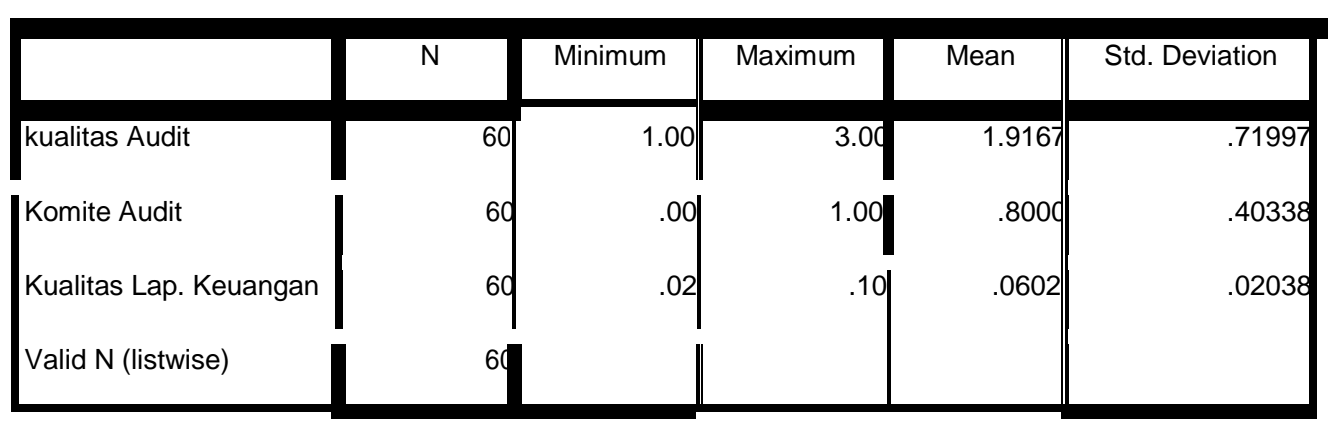

Sumber: (data diolah) menggunakan program SPSS 17.0

Berdasarkan tabel 4.1 di atas dapat dilihat bahwa variabel dependen berupa kualitas laporan keuangan melalui variabel independen memiliki nilai minimum sebesar 0,02 , nilai maksimum 0,10 , nilai mean 0,0602 , dan nilai standar deviasi 0,02038 . 


\section{Hasil Uji Hipotesis}

a. Persamaan Regresi Linear Berganda

Tabel 4.2

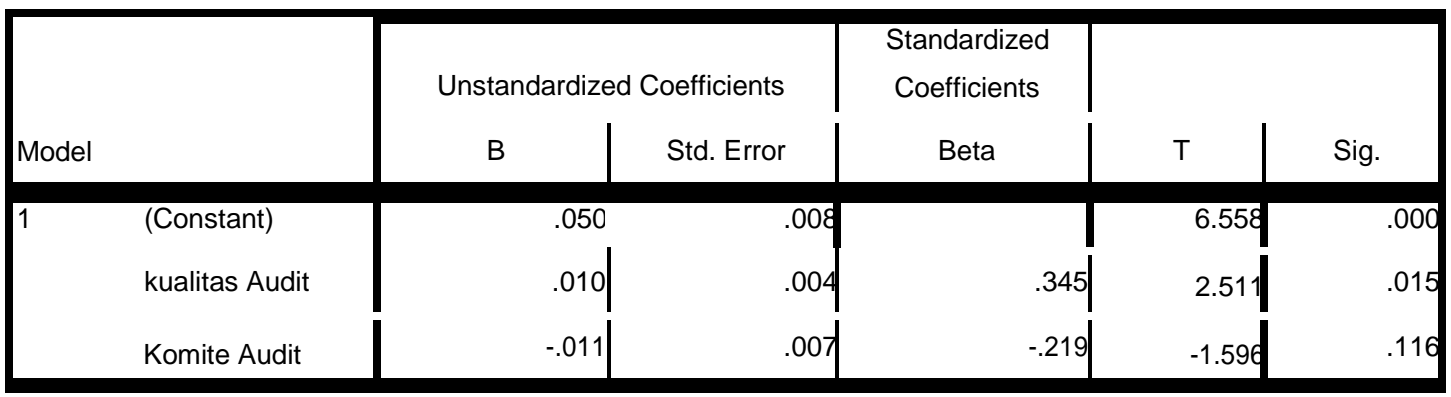

Sumber: (data diolah) menggunakan program SPSS 17.0

$\mathrm{Y}=0,050+0,010 \mathrm{X} 1+(-0,011) \mathrm{X} 2$

Yang berarti bahwa:

1) Konstanta sebesar 0,050 yang berarti jika variabel Kualitas Audit, dan Komite Audit dianggap nol maka variabel kualitas pelaporan keuangan hanya sebesar 0,050.

2) Koefisien regresi variabel Kualitas Audit diperoleh nilai sebesar 0,010 yang berarti jika variabel Kualitas Audit mengalami kenaikan sementara variabel Komite Audit diasumsikan tetap maka KualitasPelaporKeuangan juga akan mengalami kenaikan sebesar 0,010 .

\section{b. Uji Hipotesis}

Tabel 4.3

\begin{tabular}{|c|c|c|c|c|c|c|}
\hline \multirow{2}{*}{\multicolumn{2}{|c|}{ Model }} & \multicolumn{2}{|c|}{ Unstandardized Coefficients } & \multirow{2}{*}{$\begin{array}{c}\begin{array}{c}\text { Standardized } \\
\text { Coefficients }\end{array} \\
\text { Beta }\end{array}$} & \multirow[b]{2}{*}{$\mathrm{t}$} & \multirow[b]{2}{*}{ Sig. } \\
\hline & & B & Std. Error & & & \\
\hline \multirow[t]{3}{*}{1} & (Constant) & .050 & .008 & & 6.558 & .000 \\
\hline & kualitas Audit & .010 & .004 & .345 & 2.511 & .015 \\
\hline & Komite Audit & -.011 & .007 & -.219 & -1.596 & .116 \\
\hline
\end{tabular}

Sumber: (data diolah) menggunakan program SPSS 17.0

1) Hipotesis I

Berdasarkan hasil regresi terlihat bahwa variabel kualitasaudit memiliki t-hitung sebesar 2,511 dengan signifikansi 0,015. Hal ini berarti bahwa t-hitung > t-tabel $(2,511>2,003)$ maka H1 diterima dibuktikan dengan nilai 
signifikansi $0,015<0,05$. Dapat disimpulkan bahwa kualitas audit berpengaruh signifikan terhadap kualitas pelaporan keuangan.

2) Hipotesis II

Berdasarkan hasil regresi terlihat bahwa variabel komite audit memiliki thitung sebesar $-1,596$ dengan signifikansi 0,116 . Hal ini berarti bahwa thitung $<$ tabel $(-1,596<2,003)$ maka $\mathrm{H}_{2}$ ditolak dibuktikan dengan nilai signifikansi 0,116 $>0,05$. Dapat disimpulkan bahwa komite audit tidak berpengaruh signifikan terhadap kualitas pelaporan keuangan.

\section{Pembahasan}

\section{a. Pengaruh Kualitas Audit Terhadap Kualitas Laporan Keuangan}

Berdasarkan hasil uji t (parsial) dapat dilihat bahwa nilai signifikansi kualitas audit (X1) adalah 0,015 < 0,05 dan nilai thitung sebesar 2,511 yang menunjukkan bahwa kualitas audit berpengaruh signifikan terhadap kualitas laporan keuangan. Hasil ini sesuai dengan hipotesis yang telah dibuat, yang menyatakan bahwa auditor yang tergabung dalam Kantor Akuntan Publik (KAP) Big Four memiliki inisiatif yang lebih untuk menghindari hal-hal yang dapat merusak reputasinya dibandingkan KAP non Big Four, sehingga kualitas laporan keuangan yang diaudit oleh KAP Big Four lebihberkualitas. Hasil penelitian ini mendukung teori keagenan dari Jensen dan Meckling yang menjelaskan hubungan kontraktual antara pemilik atau pemegang saham dengan agen atau manajer. Dalam kontrak, agen harus berkerja sesuai delegasi wewenang dari pemilik atau pemegang saham. Namun, karena ada motivasi kepentingan pribadi yang dalam kenyataanya manajer tidak selalu bertindak sesuai keinginan pemilik. Hal ini dapat terjadi karena adanya asimetri informasi antara manajer dan pemilik, oleh karena itu dibutuhkan pihak ketiga yang independen sebagai moderator yaitu auditor eksternal yang akan memberikan opini atas kewajaran laporan keuangan yang dibuat oleh manajer. Konsisten dengan teori keagenan, manajemen perusahaan senantiasa inginmemuaskan keinginan investor dengan memilih auditor yang dapat merefleksikan citra manajer yang baik dimata investor.

Perusahaan yang terdaftar dalam Jakarta Islamic Index (JII) sebagian besar berafiliasi dengan KAP Big Four, KAP Big Four merupakan KAP yang bertaraf internasional yang memiliki 
reputasi baik dimata para klien. Untuk itu potensi terjadinya kecurangan dalam proses pengauditan semakin rendah. Keadaan ini akan berpengaruh terhadap perilaku perusahaan klien, mereka akan terdorong untuk melaksanakan pelaporan keuangan secara transparan sesuai karakteristik tata kelola perusahaan yangbaik.

Hasil ini mendukung penelitian yang dilakukan oleh Nurjannah dan Pratomo tahun 2014 yang menyatakan kualitas audit berpengaruh signifikan terhadap laporan keuangan. Dan penelitian yang dilakukan oleh Badewin tahun 2019 yang menyatakan kualitas audit berpengaruh terhadap integritas laporankeuangan.

\section{b. Pengaruh Komite Audit Terhadap Kualitas Laporan Keuangan}

Berdasarkan hasil uji t (parsial) dapat dilihat bahwa nilai signifikansi komite audit (X2) adalah 0,116>0,05 dan nilai thitung sebesar -1,596 yang menunjukkan bahwa komite audit tidak berpengaruh signifikan terhadap kualitas laporan keuangan.Komite audit merupakan auditor internal dalam suatu perusahaan, auditor internal tidak memberikan opini terhadap kewajaran laporan keuangan karena auditor internal merupakan orang dalam perusahaan yang tidak independen. Maka dari itu auditor selaku pekerja profesional harus mengandalkan kode etik jika pekerjaannya ingin dianggap bernilai dan dihargai masyarakat. Setiap auditor yang diamanati harus jujur, amanah, dan dapat dipercaya. Komite audit bertanggung jawab melakukan audit internal dan memastikan apakah perusahaan sudah memenuhi prinsip syariah. Jika komite audit melakukan tugasnya dengan baik dan sesuai prinsip syariah, maka akan menghasilkan laporan keuangan yang kredibel dan relevan. Jumlah ukuran komite audit tidak selalu mempengaruhi baik buruknya kualitas laporan keuangan perusahan. Perusahaan yang terdaftar di Jakarta Islamic Index (JII) sudah seharusnya memiliki komite audit sebagai auditor internal yang menerapkan kode etik akuntan syariah dalam mengaudit laporan keuangan perusahaan.Tetapi dalam penelitian ini komite audit tidak berpengaruh terhadap kualitas pelaporan keuangan, hal ini mungkin karena pembentukan komite audit oleh perusahaan mungkin hanya dilakukan untuk memenuhi regulasi saja, dimana di Indonesia diatur dalam peraturan No. IX.1.5 tentang "Pembentukan dan Pedoman Pelaksanaan Kerja Komite Audit". 
Komite audit merupakan pihak internal perusahaan beberapa investor kurang percaya dengan laporan keuangan karena rendahnya kredibilitas laporan keuangannya yang dikeluarkan olehperusahaan.

Hasil penelitian ini mendukung Agency Theory hubungan antara principal dan agen dapat mengarah pada informasi asimetri karena agen dianggap memiliki informasi yang lebih banyak dibandingkan dengan principal. Teori agensi mengasumsikan bahwa principal dan agen bertindak untuk memaksimalkan kepentingan diri sendiri maka dengan adanya informasi asimetri agen akan bertindak untuk menymbunyikan beberapa informasi yang tidak diketahui oleh principal, pada saat tidak ada pengawasan memberikan kesempatan pada agen untuk mempengaruhi angka-angka akuntansi pada laporan keuangan dan memanipulasi laba. Komite audit merupakan salah satu agen yang dipercayakan oleh principal. Oleh karena itu keberadaan komite audit diharapkan dapat mencegah kecurangan dan meningkatkan kualitas laporan keuangan.

Hasil ini mendukung penelitian yang dilakukan oleh Rizqy Alfiya Puteri tahun 2019 dan Pancawati Hardiningsih tahun 2010 menyatakan kualitas audit tidak berpengaruh signifikan terhadap laporan keuangan. Berbeda dengan hasil penelitian yang dilakukan oleh Badewin tahun 2019 yang menyatakan komite audit berpengaruh terhadap integritas laporankeuangan.

\section{E. Penutup}

\section{Kesimpulan}

Sesuai dengan uraian - uraian di atas serta hasil analisis data yang telah dijelaskan sebelumnya, maka dapat diambil kesimpulan sebagai berikut :

a. Secara parsial kualitas audit berpengaruh signifikan terhadap kualitas laporan keuangan. Perusahaan yang terdaftar di Jakarta Islamic Index (JII) menunjukkan kualitas audit yang baik, karena sebagian besar perusahaan berafiliasi dengan KAP bigfour. KAP bigfour merupakan auditor eksternal yang memiliki reputasi baik dimata para klien. Sehingga perusahaan mengeluarkan laporan keuangan yang dapat dipercaya dan kredibel, jika laporan keuangan perusahaan baik maka ini memberi sinyal positif kepada para investor untuk mengambilkeputusan.

b. Secara parsial komite audit tidak berpengaruh signifikan terhadap kualitas laporan keuangan. Ini menunjukkan bahwa tingginya jumlah anggota komite audit tidak selalu mempengaruhi kualitas laporan keuangan. Komite audit 
merupakan pihak internal perusahaan sehingga beberapa investor kurang percaya jika komite audit mengaudit laporan keuangan sendiri tanpa diaudit oleh pihakeksternal.

\section{Saran}

a. Dengan hasil komite audit yang menunjukkan tidak memilikipengaruh.Sebaiknya perusahaan mempertimbangkan kembali jumlah anggota komite audit yang dimiliki, terutama perusahaan dengan jumlah komite audit dibawah ketentuan minimum. Dan perusahaan sebaiknya menerapkan program secara efektif untuk meningkatkan keahlian dari anggota komite audit dengan melakukan pelatihan calon komite audit.

b. Hasil penelitian menunjukkan kualitas audit memiliki pengaruh signifikan, hal ini berarti kualitas audit yang dilakukan oleh KAP Big Four dianggap lebih berkualitas sehingga menghasilkan laporan keuangan yang baik. Perusahaan diharapkan memberikan informasi mengenai kondisi laporan keuangan perusahaan sebenarnya secara akurat dan sebenar-benarnya kepada para investor agar tidak terjadi kesalahan dalam mengambil keputusan untuk berinvestasidiperusahaan.

\section{DAFTAR PUSTAKA}

Agung Suaryana, "Pengaruh Komite Audit Terhadap Kualitas Laba". kajian Akuntansi, Vol. 2 No. 1 (Pebruari 2010),

Agus Tri Basuki dan Nano Prawoto, Analisis Regresi dalam Penelitian Ekonomi dan Bisnis (dilengkapi aplikasi SPSS \& EVIEWS)

Alvin Chandra, "Pengaruh Efektivitas Komite Audit Terhadap Relevasi Nilai Laba Bersih dan Arus Kas Dari Kegiatan Operasi”. (Tesis, Program Manajemen Kekhususan Manajemen Keuangan, Universitas Indonesia, Jakarta, 2011),

Alvin Chandra, "Pengaruh Efektivitas Komite Audit Terhadap Relevasi Nilai Laba Bersih dan Arus Kas Dari Kegiatan Operasi”. (Tesis, Program Manajemen Kekhususan Manajemen Keuangan, Universitas Indonesia, Jakarta, 2011), 
Alvin Chandra, "Pengaruh Efektivitas Komite Audit terhadap Relevansi Nilai Laba dan Arus Kas dari Kegiatan Operasi”. (Tesis Program Megister Manajemen Kekhususan Manajemen Keuangan, Jakarta, 2011),

Amir Abadi Jusuf, Auditing Pendekatan Terpadu (Jakarta, Salemba Empat, 2003),

Desi Puspitawati, "Analisis Faktor-Faktor Yang Mempengaruhi Kualitas Laporan Keuangan Pemerintah Daerah". (Tesis Ilmu Akuntansi Universitas Lampung, Bandar Lampung, 2016),

J.Supranto, Tehnik Sampeling Untuk Survey Dan Eksperimen, (Jakarta: Rineka Cipta, 2007).

Jakarta Islamic Index (JII)" (On-line), tersedia di:https://www.sahamok.com/bei/indeks-bursa/jakartaislamic-index-jii/ (10 Januari 2019)

Mathius Tandiontong, Kualitas Audit dan Pengukurannya (Bandung: Alfabeta, 2015)

Muhammad Fahdi, "Pengaruh Independensi dan Kompetensi Terhadap Kualitas Audit (Studi Empiris Pada Inspektorat Seprovinsi Riau)". Jurnal Valuta, Vol. 4 No. 2 (Oktober 2018),

Muhammad Fahdi, "Pengaruh Independensi dan Kompetensi Terhadap Kualitas Audit (Studi Empiris Pada Inspektorat Seprovinsi Riau)". Jurnal Valuta, Vol. 4 No. 2 (Oktober 2018),

Munawir, Analisa Laporan Keuanggan (Yogyakarta: Liberty, 2007),

Pancawati Hardiningsih, “ Pengaruh Independensi, Corporate Governance, dan Kualitas Audit Terhadap Integritas Laporan Keuangan". Kajian Akuntansi, Vol. 2 No. 1 (Pebruari 2010), 
Pancawati Hardiningsih, " Pengaruh Independensi, Corporate Governance, dan Kualitas Audit Terhadap Integritas Laporan Keuangan". Kajian Akuntansi, Vol. 2 No. 1 (Pebruari 2010),

Rizki Rudiantoro, Sylvia Veronica Siregar, "Kualitas Keuangan UMKM Serta Prospek Implementasi SAK ETAP”. Jurnal Akuntansi dan Keuangan Indonesia, Vol. 9 No. 01 (Juni 2012),

Sugiono,Metode Penelitian Pendidikan Pendekatan Kualitatif, Kuantitatif, dan $R \& D$, Cetakan ke-26 (Bandung: Alfabeta, 2017),

Suharyadi Purwanto, Statistika untuk Ekonomi dan Keuangan Modern (Jakarta: Salemba Empat,2016),

Tulus Suryanto. “Manajemen Laba Pada Bank Syariah Di Indonesia: Peran Komite Audit Dan Dewan Pengawas Syariah" KINERJA, Vol. 18 No. 1 (2014), 